University of Vermont

UVM ScholarWorks

Rubenstein School of Environment and Natural Rubenstein School of Environment and Natural Resources Faculty Publications

$10-1-2010$

\title{
The Amazon frontier of land-use change: Croplands and consequences for greenhouse gas emissions
}

\author{
Gillian L. Galford \\ Ecosystems Center \\ Jerry Melillo \\ Ecosystems Center \\ John F. Mustard \\ Brown University \\ Carlos E.P. Cerri \\ Universidade de Sao Paulo - USP \\ Carlos C. Cerri \\ Universidade de Sao Paulo - USP
}

Follow this and additional works at: https://scholarworks.uvm.edu/rsfac

Part of the Agriculture Commons, Climate Commons, and the Sustainability Commons

\section{Recommended Citation}

Galford GL, Melillo J, Mustard JF, Cerri CE, Cerri CC. The Amazon frontier of land-use change: croplands and consequences for greenhouse gas emissions. Earth Interactions. 2010 Oct 28;14(15):1-24.

This Article is brought to you for free and open access by the Rubenstein School of Environment and Natural Resources at UVM ScholarWorks. It has been accepted for inclusion in Rubenstein School of Environment and Natural Resources Faculty Publications by an authorized administrator of UVM ScholarWorks. For more information, please contact scholarworks@uvm.edu. 
Earth Interactions - Volume 14 (2010) - Paper No. 15 • Page 1

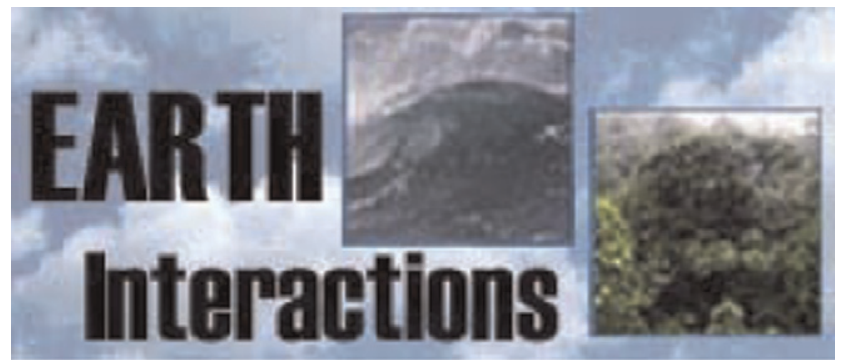

Copyright (C 2010, Paper 14-015; 9310 words, 9 Figures, 0 Animations, 6 Tables. http://EarthInteractions.org

\section{The Amazon Frontier of Land-Use Change: Croplands and Consequences for Greenhouse Gas Emissions}

\section{Gillian L. Galford*,+}

The Ecosystems Center, Marine Biological Lab, Woods Hole, Massachusetts, and Geological Sciences, Brown University, Providence, Rhode Island

\section{Jerry Melillo}

The Ecosystems Center, Marine Biological Lab, Woods Hole, Massachusetts

\section{John F. Mustard}

Geological Sciences, Brown University, Providence, Rhode Island

\section{Carlos E. P. Cerri}

Escola Superior de Agricultura Luiz de Queiroz, Universidade de São Paulo, Piracicaba, Brazil

\section{Carlos C. Cerri}

Centro de Energia Nuclear na Agricultura, Universidade de São Paulo, Piracicaba, Brazil Received 11 January 2010; accepted 1 July 2010

* Current affiliation: Earth Institute, Columbia University, Palisades, New York.

+ Corresponding author address: Gillian Galford, Earth Institute, Columbia University, 102A Geosciences, Lamont Campus, 61 Route 9W, P.O. Box 1000, Palisades, NY 10964.

E-mail address: gg2405@columbia.edu 
Earth Interactions - Volume 14 (2010) - Paper No. 15 • Page 2

\begin{abstract}
The Brazilian Amazon is one of the most rapidly developing agricultural frontiers in the world. The authors assess changes in cropland area and the intensification of cropping in the Brazilian agricultural frontier state of Mato Grosso using remote sensing and develop a greenhouse gas emissions budget. The most common type of intensification in this region is a shift from single- to doublecropping patterns and associated changes in management, including increased fertilization. Using the enhanced vegetation index (EVI) from the Moderate Resolution Imaging Spectroradiometer (MODIS) sensor, the authors created a green-leaf phenology for 2001-06 that was temporally smoothed with a wavelet filter. The wavelet-smoothed green-leaf phenology was analyzed to detect cropland areas and their cropping patterns. The authors document cropland extensification and doublecropping intensification validated with field data with $85 \%$ accuracy for detecting croplands and 64\% and 89\% accuracy for detecting single- and double-cropping patterns, respectively. The results show that croplands more than doubled from 2001 to 2006 to cover about $100000 \mathrm{~km}^{2}$ and that new double-cropping intensification occurred on over $20 \%$ of croplands. Variations are seen in the annual rates of extensification and double-cropping intensification. Greenhouse gas emissions are estimated for the period 2001-06 due to conversion of natural vegetation and pastures to row-crop agriculture in Mato Grosso averaged $179 \mathrm{Tg} \mathrm{CO}_{2}-\mathrm{e} \mathrm{yr}^{-1}$, over half the typical fossil fuel emissions for the country in recent years.
\end{abstract}

KEYWORDS: Carbon; Deforestation; Remote sensing; Agricultural intensification; Soybean; Cerrado

\title{
1. Introduction
}

Today, agricultural land occupies almost $40 \%$ of Earth's land surface, with rapid growth in tropical regions (Foley et al. 2005; Hansen et al. 2008). Economic development and global markets have driven large-scale conversions of tropical ecosystems to agricultural use in recent decades (Nepstad et al. 2006). Local changes in land cover and land use in tropical regions have become increasingly linked to national and international demands, moving away from subsistence agriculture to large-scale, heavily mechanized agriculture. These shifts in land cover and land use can have large environmental impacts including the release of greenhouse gases through biomass burning and biogeochemical processes affected by clearing activities (Forster et al. 2007).

Detailed measurements of tropical land-clearing activities at high temporal and spatial resolution are essential for improving estimates of impacts on carbon emissions, biogeochemical cycles, climate, and biodiversity (Hansen et al. 2008). Land clearing is particularly evident in the Brazilian Amazon, where the deforestation rate reached a high of $27772 \mathrm{~km}^{2} \mathrm{yr}^{-1}$ in 2004 (INPE 2008). Mato Grosso state (Figure 1) is a global hotspot of tropical deforestation and is a major contributor to the Brazilian Amazon "arc of deforestation," because the state accounts for 38\% of Amazon deforestation since 2000 (Hansen et al. 2008; INPE 2008). The clearing of forests to create pastures has been the dominant land-use transition in this region for decades. Initial clearings were government supported for colonization and border security, giving way to pasture development through various government aid programs. Today, pasture remains the largest land use in the Amazon, but its rate of growth is outpaced by the recent, rapid growth of rowcrop agriculture, particularly in the southern Amazon state of Mato Grosso (Barona 


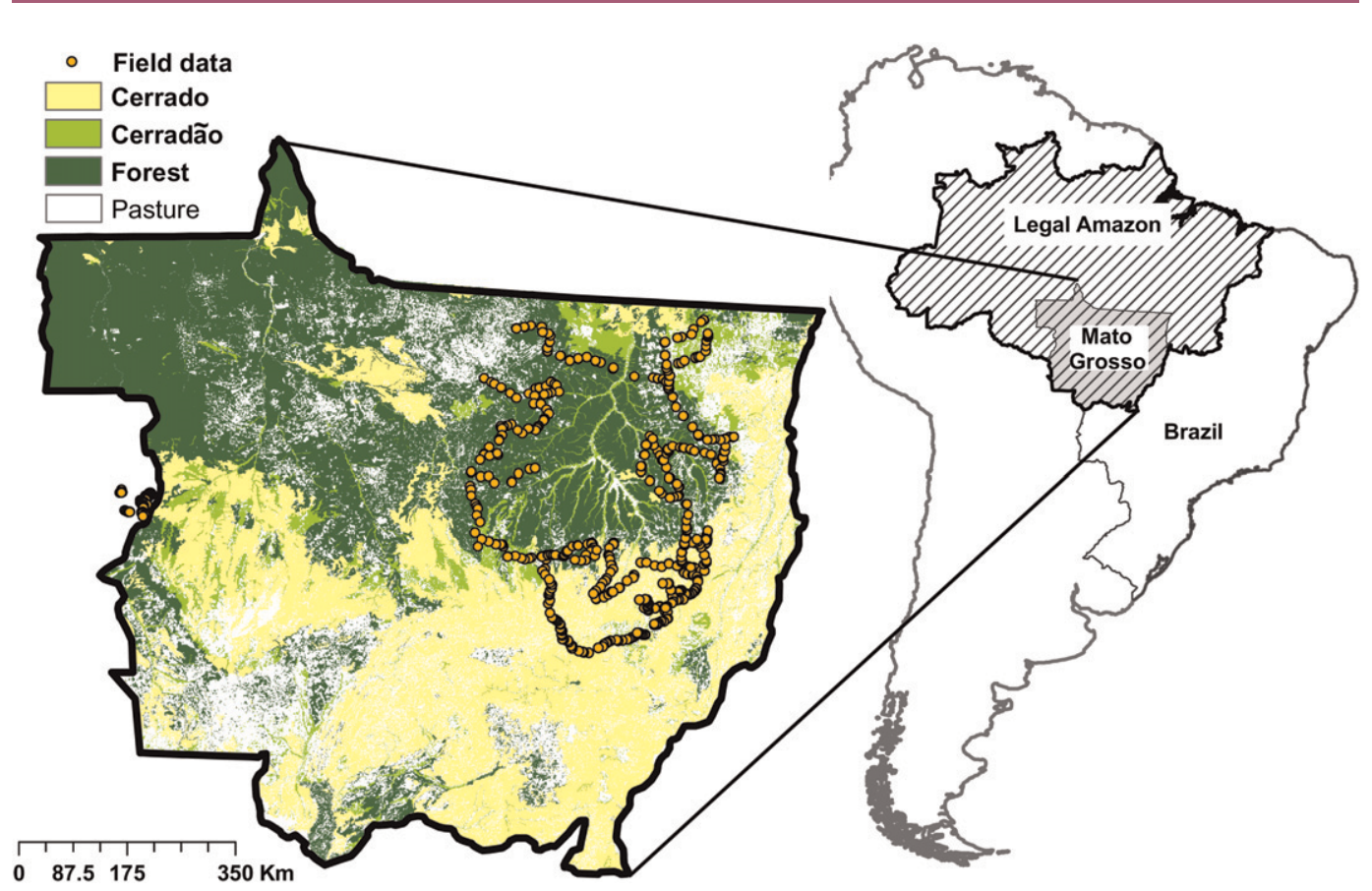

Figure 1. Mato Grosso state, the frontier of agricultural development in the Brazilian Amazon, is shown here in the context of the Brazilian legal Amazon and with potential natural vegetation (Mello 2007) and the extent of pastures in 2001 (Morton et al. 2006; Morton et al. 2009). Field data points used for validation are shown with orange dots.

2008; Brown et al. 2005; Nepstad et al. 2006). These cropland operations are very large. Over $75 \%$ of the mechanized soybean farms cultivate areas ranging from 500 to over 5000 ha (Fundação Agrisus 2006). The rapid growth in row-crop agriculture has been enabled by recent advances in mechanized farm technology, crop breeding, and crop engineering in response to global product demand and national development activities (Brown et al. 2007; Fearnside 2001; Nepstad et al. 2006). The result has been large-scale conversions of natural ecosystems or lowerproduction agricultural lands (e.g., pasture) to row-crop agriculture (Jepson et al. 2008). Large-scale deforestation continues with little transition back to forest (Rudel et al. 2005). In the agricultural frontier of the Brazilian Amazon, the major expansion of croplands with mechanized agriculture is emerging as a significant new dynamic that needs to be further examined (Morton et al. 2006).

The dynamics of land use in Mato Grosso are complex and represent a variety of pathways leading to cropland establishment (Figure 2). Desired increases in crop production may be met through clearing natural lands for additional agricultural production (extensification) or through increased production on existing agricultural lands (intensification; Boserup 1965). In Mato Grosso, cropland extensification involves land clearing through slash and burn and leaves no residual slash or woody debris that could hinder the mechanized tilling and planting. Intensification, or the increased production per unit area or per unit time by switching patterns of agricultural management, can be implemented in many different ways, 
Earth Interactions - Volume 14 (2010) • Paper No. 15 • Page 4

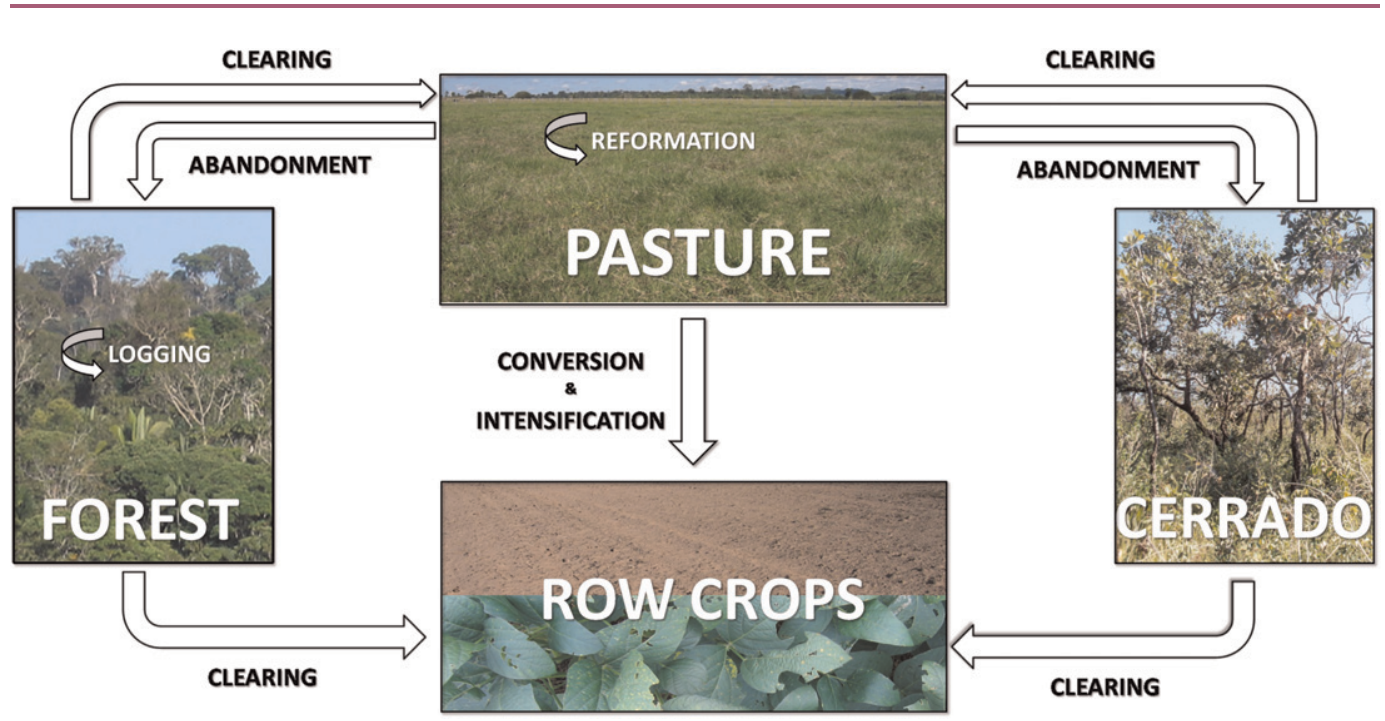

Figure 2. Dominant land-use trajectories for Mato Grosso. The foci of this paper are transitions to row-crop agriculture and intensification within existing croplands.

including shifting cropping patterns, transforming pastures to croplands, selecting new cultivars, controlling weedy growth and pests, using irrigation, and adding nutrients (Gregory et al. 2002; Keys and McConnell 2005). A change in croppingpattern intensity, such as increased plantings of the same crop or a shift in cultivars, is a common type of intensification well documented in other parts of the world (Turner and Ali 1996). In Mato Grosso, increased production per area from intensification occurs by changing cropping patterns from single cropping (typically soybean) to double cropping (typically soybean followed by corn) in one growing season, enabled by the use of fertilizers in the double-cropping system (Fundação Agrisus 2006). Quantification of the space-time dynamics associated with expanding croplands and changing cropping patterns is critical for many areas of ecological assessment and agricultural sustainability, including improved estimates of greenhouse gas emissions, regional climate modeling, hydrological cycling, biodiversity monitoring, and agricultural soil fertility.

To document and understand land-cover and land-use change over broad spatial and temporal scales, we have come to rely on remote sensing, particularly in large areas such as the Amazon (Adams et al. 1995; Alves 2002; Skole and Tucker 1993). Since 1988, the Brazilian government has used remote sensing analyses to track deforestation for enforcement of forest protection laws, often with great success but also with some uncertainty because of relatively infrequent repeated measurements, the limitations of validation over such a large and remote area as the Amazon, and conservative detection techniques used to minimize false positives (INPE 2008). Today, we can reduce the error in these estimates using higherfrequency observations provided by the Moderate Resolution Imaging Spectroradiometer (MODIS; Justice 1998) and even distinguish among pasture, crops, and natural land cover (Anderson et al. 2005; Brown et al. 2005; Galford et al. 2008; Morton et al. 2005). Recent studies using remote sensing data have moved beyond 
Earth Interactions - Volume 14 (2010) • Paper No. 15 • Page 5

detection of deforestation to analyses of more complex land-use phenomena, such as fire frequency and transitions of natural areas and pastures to croplands (Galford et al. 2008; Morton et al. 2008).

The creation of croplands and evolution of cropping patterns are well-known land-use changes in this region (Fundação Agrisus 2006) but remain unquantified by previous remote sensing studies or by government records (surveys and census data). In this analysis, we quantitatively assess the rates of change associated with these processes using new observations from remotely sensed data, coupled with validation work. We also estimate the consequences of the land-use changes on regional greenhouse gas emissions, with a focus on carbon dioxide and methane emissions associated with cropland establishment and management and nitrous oxide emissions associated with crop fertilization.

\section{Materials and methods}

\subsection{Study area}

The state of Mato Grosso (Figure 1) is located in the southern part of the Amazon and has an area of $925225 \mathrm{~km}^{2}$. The region's natural vegetation includes forest, cerradão (savanna woodland), and cerrado (scrub savanna). The Amazon forest has long been recognized for its high biodiversity and role in the global climate as well as for threats to it from deforestation and logging (Dale et al. 1994; Shukla et al. 1990; Skole and Tucker 1993). The cerrado and cerradão of Brazil are less well known but are one of the world's biodiversity hot spots threatened by agricultural development. To date, two-thirds of the Brazilian cerrado and cerradão has been converted to agriculture (Klink and Machado 2005; Myers et al. 2000). Much of the remaining intact cerrado and cerradão are in Mato Grosso, but the threat of agricultural conversion creates a challenging juxtaposition of agricultural development and conservation priorities (Conservation International 2008; Klink and Machado 2005; Mello 2007).

\subsection{Remote sensing of croplands}

We used newly developed remote sensing techniques (Galford et al. 2008) to analyze MODIS data to detect croplands and the evolution of cropping patterns in Mato Grosso. We created a MODIS enhanced vegetation index (EVI; Huete et al. 2002) time series from 8-day composite surface reflectance data at a moderately coarse resolution of $500 \mathrm{~m}$, appropriate for the size of croplands in Mato Grosso, where a majority of the farms are over 500 ha (Alves 2002; Fundação Agrisus 2006). For this MODIS product, the reflectance value of each pixel represents the best observation over the 8-day period, so there may be several different observation dates within one image. A time series can be skewed by assuming the file name, which corresponds to the first day of the 8-day period, is the actual observation date for a given pixel. To create a more accurate time series, the actual observation date of each pixel was extracted from the MODIS data product's "date of observation flag" instead of using a single date of observation for all pixels (Galford et al. 2008). We stacked the EVI observations into a time series of 
Earth Interactions - Volume 14 (2010) • Paper No. 15 • Page 6

remotely sensed green-leaf phenology. Because of the frequent anomalous observations (noise) in these data from clouds and other instrument and observation effects, we temporally smoothed the time series with a wavelet transform to distinguish true phenological peaks from noise. Croplands were detected from the wavelet-smoothed time series by their characteristically high annual standard deviation of green-leaf phenology, because crops have large annual phenological changes as they go from essentially bare soil to extremely uniform green cover. The results are grouped into classes of cropland with the cropland class divided into subclasses based on single- and double-cropping patterns from the number of phenological peaks in the wavelet-smoothed time series over the growing year. We have named the growing year for the year of harvest (e.g., August 2000-July 2001 would represent the 2001 growing year), which allows us to track the wet season growth peaks. Each year was analyzed independently of its class from the previous year. Galford et al. (Galford et al. 2008) discuss this methodology in detail.

Further phenological analyses of single- and double-cropping patterns were used to determine areas of extensification (new croplands) and double-cropping intensification (a shift from single to double cropping). We used the 2001 growing year as the baseline year for quantifying change. We classed "extensification" as any area that moved from "not cropland" in 2001 to "cropland" in any subsequent year and remained in cropland through 2006. We identified the source ecosystem cleared for the cropland using the potential natural vegetation map, or the extent of natural vegetation were there no land use, of Mello (Mello 2007) to calculate greenhouse gas emissions. Mello (Mello 2007) collected and compiled natural vegetation data from various state-level offices in Mato Grosso using a geographic information system (GIS).

Besides natural vegetation, croplands may also be derived from pastures. We combined our cropland classification scheme, the natural vegetation map (Mello 2007), and pasture maps generated elsewhere but covering almost the same study period (2001-05; Morton et al. 2009; Morton et al. 2006) to determine these landuse transitions. For 2006, new pasture areas were assumed to have a linear relationship based on the 2001-05 period, and their distribution was weighted by biome. Our approach allows us to identify where and when new croplands are developed directly from each natural ecosystem or from pastures. In the case of pastures, we can identify the natural ecosystem from which they have been derived. The pasture dataset is likely an overestimate of planted pasture in the cerrado region, because it includes natural (unmanaged) grasslands that may not be grazed. Despite these caveats, this is the best spatially explicit estimate of pasture lands available to us for the study period. Pasture-to-cropland transitions were identified where new croplands were detected in areas mapped as pasture in the previous growing season.

To create a spatially coherent product, we smoothed the cropping-pattern classes using a $3 \times 3$ pixel window to sieve outlying classes, designating them as unclassed (ITT 2008). Unclassed pixels were then clumped (ITT 2008) into the dominant class within the $3 \times 3$ pixel window. Cropping-pattern classes from the sieving and clumping procedure were then validated against field data (see section 2.3 for further discussion of validation). After validation, we restricted analysis to Mato Grosso. 
Earth Interactions • Volume 14 (2010) • Paper No. 15 • Page 7

Table 1. Description of field datasets used for accuracy assessment for the classes of cropland and cropping patterns detected with remote sensing.

\begin{tabular}{|c|c|c|c|}
\hline Dataset & Methods & Spatial data & Year \\
\hline Brown et al. 2007 & $\begin{array}{l}\text { Farm interviews and mapping for } \\
\text { land-use history }\end{array}$ & $\begin{array}{l}\text { Field mapping as } \\
\text { polygons }\end{array}$ & 2005 \\
\hline Galford 2010 & $\begin{array}{l}\text { Farm records and mapping for } \\
\text { land-use history }\end{array}$ & $\begin{array}{l}\text { Field mapping as } \\
\text { polygons }\end{array}$ & 2006 \\
\hline $\begin{array}{l}\text { C. M. Stickler } 2006 \text {, } \\
\text { personal communication }\end{array}$ & $\begin{array}{l}\text { Regional transect observations of } \\
\text { land-cover and land-use changes }\end{array}$ & GPS point data & 2006 \\
\hline
\end{tabular}

\subsection{Remote sensing validation}

We used three new cropland datasets for validation (Table 1). Each dataset documents observed land uses at the time of field visits and/or reconstructed land uses from farm records and GIS maps generated by the researchers or provided by the farms. We included validation points from farms on the border of Mato Grosso, in the neighboring state of Rondônia, to increase the validation dataset. This is a soybean-growing region similar to the croplands in Mato Grosso, and the data from this area were treated the same as the other field data. Rondônia was not included in the final cropland analysis, because croplands are only a minor land use on the state scale. Each dataset had a slightly different spatial format, such as point observations or polygons of field areas.

We standardized the representation of the ground-truth observations to facilitate validation. First, all datasets were converted to point data (Figure 1) and matched to the corresponding pixels of the remote sensing classified images. Errant field points were identified in a cloud-free 2005 MODIS reflectance image and removed by hand if they met one of the following criteria: 1) points occur on mixed pixels (e.g., forest edges as recorded in the field notes); 2) two points recording the same land use occur in one pixel that would cause double counting; or 3) two points reporting different land uses occur in one pixel, because we cannot say which use makes up the majority of the pixel. The points in these datasets are not randomly stratified across the classes, because they were collected for purposes other than this validation exercise. They may overrepresent forested areas and double-cropping patterns, but these are the best available field data at the scale and detail required for validation.

For further validation, we used Instituto Brasileiro de Geografia e Estatística (IBGE; IBGE 2009) annual estimates of croplands to compare with the remote sensing results. We assessed the accuracy of our aggregate statewide cropland area detection by direct comparison to the statewide numbers reported by IBGE (IBGE 2009). Annual production records are aggregated by IBGE from monthly data under the direction of the Coordenador Estadual de Pesquisas Agropecuárias (state coordinator of agricultural research) with the aid of the IBGE data collection network; other local government offices; and the producers at "município" (equivalent to a U.S. county), regional, and state levels (IBGE 2002). We used the state-level data because of uncertainties in the finer-scale records related to how data are collected and reported. For example, data are collected for each município, but the total cropland area in one município may be larger than the total area in the 
Earth Interactions - Volume 14 (2010) • Paper No. 15 • Page 8

Table 2. Biomass estimates (above ground + below ground) used to calculate carbon savings and losses.

\begin{tabular}{lcl}
\hline Land cover or land use & Carbon $\left(10^{6} \mathrm{~g} \mathrm{ha}^{-1}\right)$ & \multicolumn{1}{c}{ Reference(s) } \\
\hline Forest & $130^{\mathrm{a}}$ & Saatchi et al. 2007; Saatchi et al. 2009 \\
Cerradão & 130 & Houghton et al. 2001 \\
& $98^{\mathrm{a}}$ & Nogueira et al. 2008 \\
& $113^{\mathrm{b}}$ & Saatchi et al. 2007 \\
Cerrado & $195^{\mathrm{c}}$ & Saatchi et al. 2007 \\
& $13^{\mathrm{a}}$ & Castro and Kauffman 1998 \\
& $33^{\mathrm{b}}$ & Ministry of Science and Technology 2006 \\
Pasture (well managed) & $45^{\mathrm{c}}$ & Saatchi et al. 2009 \\
\hline
\end{tabular}

${ }^{\mathrm{a}}$ The low estimate used.

$\mathrm{b}$ The estimate used here.

c The high estimate used.

município, because a single farm may straddle two municípios and the cropland area will be reported in the município housing the farm headquarters. Comparing remote sensing results to the government estimates on a larger, aggregated level removed some of these smaller-scale artifacts.

\subsection{Estimating greenhouse gas emissions}

We used a bookkeeping model to calculate greenhouse gas emissions from the carbon losses associated with land-cover and land-use change as well as the nitrous oxide losses associated with nitrogen fertilizers applied in croplands. We focused on greenhouse gas emissions from the formation and fertilization of croplands. These components of the regional greenhouse gas budget have not been well studied to this point and compliment other well-studied components of the regional budget (e.g., DeFries et al. 2008; Steudler et al. 1996).

\subsubsection{Carbon emissions from land-cover and land-use change}

We estimated the biomass lost during land-use conversions to croplands by accounting for the area affected as determined from remote sensing inputs and for biomass per unit area for each of the major biome types using median values from the literature (Table 2). We assumed constant biomass values across each biome. In Mato Grosso, abandonment of croplands is rare (Rudel et al. 2005), so vegetation regrowth is not considered.

We assumed all natural biomass was completely lost by burning during land conversion because cultivation practices, such as plowing and harvesting with large machinery, require fields to be free of roots, stumps, and other forest remnants that could damage farm equipment. Unlike clearing for pastures, where some trees are left standing and many stumps and logs persist for decades, croplands are devoid of any signs of the former land cover.

Greenhouse gas emissions due to the loss of biomass in land-use transitions were calculated separately for forests and nonforest ecosystems. For forest clearing, carbon is released from biomass burning predominantly as carbon dioxide with a minor component released as methane (Andreae and Warneck 1994; Cofer et al. 
1996; Hao and Ward 1993). For the Amazon forest, we assumed a $\mathrm{CH}_{4}-\mathrm{C}_{2} \mathrm{CO}_{2}-\mathrm{C}$ emission ratio of 1.1\% (Longo et al. 2009; Steudler et al. 1996). No release of methane is assumed to occur during the conversion of nonforest (pasture, cerrado, and cerradão) ecosystems to croplands. These carbon greenhouse gas emissions $\left(\mathrm{GHG}_{\mathrm{CARBON}}\right)$, reported in grams $\mathrm{CO}_{2}$-equivalents $\left(\mathrm{CO}_{2}\right.$-e $)$, were estimated as follows:

$$
\mathrm{GHG}_{\mathrm{CARBON}}=\mathrm{GHG}_{\mathrm{NON}-\mathrm{FOREST}}+\mathrm{GHG}_{\mathrm{FOREST}}
$$

$$
\begin{aligned}
\mathrm{GHG}_{\text {NON-FOREST }}= & \mathrm{C}_{\mathrm{BIOMASS}} \times(\text { Area }) \\
& \times\left(44 \mathrm{~g} \mathrm{CO}_{2} / 12 \mathrm{~g} \mathrm{C}\right) \times\left(\mathrm{GWP}_{\mathrm{CO} 2}\right), \text { and }
\end{aligned}
$$

$$
\begin{aligned}
\mathrm{GHG}_{\mathrm{FOREST}}= & {\left[(0.989) \times\left(\mathrm{C}_{\mathrm{BIOMASS}}\right) \times(\text { Area }) \times\left(44 \mathrm{~g} \mathrm{CO}_{2} / 12 \mathrm{~g} \mathrm{C}\right)\right.} \\
& \left.\times\left(\mathrm{GWP}_{\mathrm{CO} 2}\right)\right]+\left[(0.011) \times\left(\mathrm{C}_{\mathrm{BIOMASS}}\right) \times(\text { Area })\right. \\
& \left.\times\left(16 \mathrm{~g} \mathrm{CH}_{4} / 12 \mathrm{~g} \mathrm{C}\right) \times\left(\mathrm{GWP}_{\mathrm{CH} 4}\right)\right]
\end{aligned}
$$

where $\mathrm{C}_{\mathrm{BIOMASS}}$ is the carbon content of the biomass $\left(\mathrm{g} \mathrm{C} \mathrm{ha}^{-1}\right)$ of pasture or natural land cover (Table 2), area is the land area (ha) converted to crops, GWP $\mathrm{CO}_{2}$ is the 100-yr global warming potential (GWP) of carbon dioxide (1), and $\mathrm{GWP}_{\mathrm{CH} 4}$ is the 100-yr GWP of methane (25; Forster et al. 2007).

\subsubsection{Fertilizer nitrous oxide emissions}

We estimated total fertilizer use as a function of area by cropping pattern. We assumed that single crops are soybean, as is typical in the region (Fundação Agrisus 2006), with a fertilizer input of $10 \mathrm{~kg} \mathrm{~N}^{-1}$. Soybean agriculture typically does not require nitrogen additions, but most farmers in the region add this modest amount as "insurance." Double-cropping systems may require fertilizer applications when the second crop (corn) is planted, in which case no additional fertilizer is applied to the first crop.

To estimate the mean amount $\mathrm{N}$ fertilizer applied for corn planted in a doublecropping pattern, we combined farm records of fertilizer use and field trial fertilization rates needed to produce the mean corn yields in Mato Grosso. Studies show that corn may require up to $120 \mathrm{~kg} \mathrm{~N} \mathrm{ha}^{-1}$ to reach optimal productivity (Mar et al. 2003; Rezende Pereira et al. 2009), but the total $\mathrm{N}$ fertilizer added may be somewhat reduced by the $\mathrm{N}$ fixed by the soybean grown as the first crop. Data from government surveys show that Mato Grosso corn crops have an average yield of 3.71 metric tons $\mathrm{ha}^{-1}$ (IBGE 2009). Field trials in the Amazon forest and cerrado regions achieve these productivity levels with fertilizer doses ranging from 0 to $77 \mathrm{~kg} \mathrm{~N}^{-1}$ (Cruz et al. 2005; de Carvalho et al. 2008; Mar et al. 2003; Souza and Sorrato 2006). Recommended fertilizer doses range from 34 to $120 \mathrm{~kg} \mathrm{~N}^{-1}$ (Broch and Pedroso 2008; Broch and Pedroso 2009; de Carvalho et al. 2008). Farm records from the Amazon show a comparatively low dose of $\mathrm{N}$ fertilizer is typically used, with a mean of $23 \mathrm{~kg} \mathrm{~N}^{-1}$ (range from 0 to $70 \mathrm{~kg} \mathrm{~N}^{-1}$; Cerri et al. 2007; Edgar 2007; Galford 2010). From these sources, the average $\mathrm{N}$ fertilization 
Earth Interactions - Volume 14 (2010) - Paper No. 15 • Page 10

Table 3. Validation results (pixel counts) for remotely sensed classes of cropping patterns compared to the collective pool of all field datasets. Overall accuracy was $85.6 \%$.

\begin{tabular}{lccccc}
\hline \multirow{2}{*}{$\begin{array}{c}\text { Remotely } \\
\text { sensed classes }\end{array}$} & Field data & Row & $\begin{array}{c}\text { User's } \\
\text { accuracy }\end{array}$ \\
\cline { 2 - 4 } Single cropping & Single cropping & Double cropping & Noncropland & & $\begin{array}{c}\text { total } \\
\text { Double cropping }\end{array}$ \\
Not row crop & 26 & 16 & 50 & 113 & $41.6 \%$ \\
Column total & 0 & 163 & 4 & 193 & $84.5 \%$ \\
Producer's accuracy & 73 & 4 & 383 & 387 & $99.0 \%$ \\
\hline
\end{tabular}

for corn as a secondary crop is $34.3 \mathrm{~kg} \mathrm{~N} \mathrm{ha}^{-1}$ (Broch and Pedroso 2008; Broch and Pedroso 2009; Cerri et al. 2007; Cruz et al. 2005; Edgar 2007; de Carvalho et al. 2008; Galford 2010; Mar et al. 2003; Souza and Sorrato 2006). For this work, we used the average fertilizer rate $\left(34 \mathrm{~kg} \mathrm{~N} \mathrm{ha}^{-1}\right)$ for second crops and included a high $\left(75 \mathrm{~kg} \mathrm{~N} \mathrm{ha}^{-1}\right)$ and low range $\left(0 \mathrm{~kg} \mathrm{~N} \mathrm{ha}^{-1}\right)$ in our sensitivity analysis. We then used the area in single and double crops to estimate greenhouse gas emissions (in $\mathrm{CO}_{2}-\mathrm{e}$ ) associated with fertilizer $\mathrm{N}_{2} \mathrm{O}$ losses $\left(\mathrm{GHG}_{\mathrm{N} 2 \mathrm{O}}\right)$,

$$
\mathrm{GHG}_{\mathrm{N} 2 \mathrm{O}}=0.03 \text { Fertilizer Area }\left(44 \mathrm{~g} \mathrm{~N}_{2} \mathrm{O} / 28 \mathrm{~g} \mathrm{~N}\right) \mathrm{GWP}_{\mathrm{N} 2 \mathrm{O}} \text {, }
$$

where $3 \%$ of the applied $\mathrm{N}$ fertilizer is lost as $\mathrm{N}_{2} \mathrm{O}$ (Crutzen et al. 2008; Scanlon and Kiely 2003), fertilizer is the $\mathrm{N}$ fertilizer dose in $\mathrm{g} \mathrm{N} \mathrm{ha}^{-1}$ (10 $000 \mathrm{~g} \mathrm{~N}^{-1}$ for single crop and $34000 \mathrm{~g} \mathrm{ha}^{-1}$ for double crop), area is the land area (ha) being fertilized, and $\mathrm{GWP}_{\mathrm{N} 2 \mathrm{O}}$ is the 100-yr GWP of nitrous oxide (300; Forster et al. 2007).

\section{Results}

\subsection{Remote sensing accuracy}

We assessed our accuracy in remote sensing analyses with the comparison of field data using overall accuracy, producer's and user's accuracy, and KAPPA $K_{\text {hat }}$ metrics (Table 3). We find that our overall accuracy is $86 \%$. Further accuracy assessments were conducted to better represent the nature of the dataset. The producer's accuracy is a measure of omission by using column totals, and the user's accuracy is a measure of commission using row totals. The KAPPA $K_{\text {hat }}$ statistic assesses accuracy while accounting for the off-trace elements from the error matrix. A $K_{\text {hat }}$ value close to one is much better than a random classification, zero is random, and negative numbers are worse than random (Jenson 2005). Croplands were detected with producer's accuracy of $98 \%$ and user's accuracy of $82 \%$. The $K_{\text {hat }}$ for the cropland and noncropland classes was 0.82 . For the detection of mechanized agriculture single- and double-cropping land use, producer's and user's accuracies were $64 \%$ and $42 \%$ for single crops and $89 \%$ and $84 \%$ for double crops, respectively. The $K_{\text {hat }}$ statistic for noncroplands and single- and double-crop classes was 0.74 . The field data underrepresent single crops (Table 3), because many of the field sites had no recorded single crops and were not representative of the region, so this may be a bias that causes the validation to suggest that the remote sensing may systematically underestimate the presence of single crops. 
Earth Interactions V Volume 14 (2010) - Paper No. 15 • Page 11

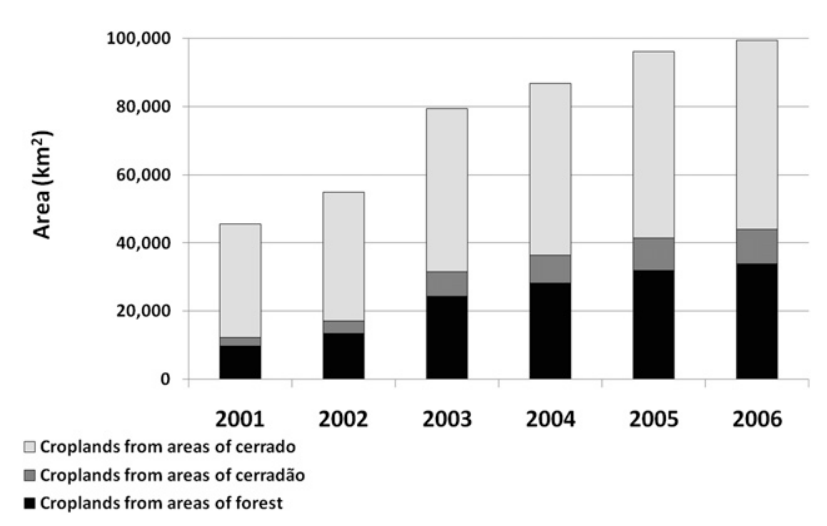

Figure 3. Total cropland area $\left(\mathrm{km}^{2}\right)$ in Mato Grosso by natural ecosystem of origin.

Our statewide estimates of cropland area (see section 3.2.1) generally agree with government estimates (IBGE 2009). The remote sensing estimates tend to underrepresent the cropland area. On average across the study period, the remote sensing data detects $65 \%$ of the cropland estimated in IBGE 2009. Looking at individual years, the lowest agreement between these datasets is 40\% in year 2001 and the highest is $82 \%$ in year 2003 .

\subsection{Changes in croplands}

\subsubsection{Cropland extensification}

Total cropland area in Mato Grosso more than doubled from 2001 to 2006, increasing from 45497 to $99488 \mathrm{~km}^{2}$ (Figure 3). We document an average annual rate of increase for agricultural extensification of $0.47 \%$. By 2006, Mato Grosso croplands covered $11 \%$ of the state (Figure 4).

We see different cropland extensification rates for the different natural biomes (Figure 4). When weighted by area of potential natural vegetation type, the cerrado supplied the largest relative amount of land for croplands, with croplands accounting for $18 \%$ of the cerrado's potential area as estimated by Mello (Mello 2007). Over $22000 \mathrm{~km}^{2}$ of new croplands emerged in the cerrado biome, a $10 \%$ increase in cropland area for Mato Grosso's cerrado region (Figure 4). Spatially, we see that new extensification occurs around areas of previously existing croplands, giving a "clumping" effect to the cropland distribution (Figure 5).

Rates of conversion to cropland vary by land-cover and land-use sources and exhibit interannual variability. On average, over $60 \%$ of conversions in the cerrado region were two-phase transitions: cerrado to pasture and then pasture to cropland Figure 6). In the cerradão regions, $70 \%$ of new croplands followed such a twophase transition. The sequence of forest-to-pasture and then pasture-to-cropland conversions accounted for over $60 \%$ of the forest land-use transitions, and total cropland area in this region increased $24200 \mathrm{~km}^{2}$ over the study period. The rates of pasture-to-cropland transitions show high interannual variability, particularly in areas of former cerrado (Table 4). 


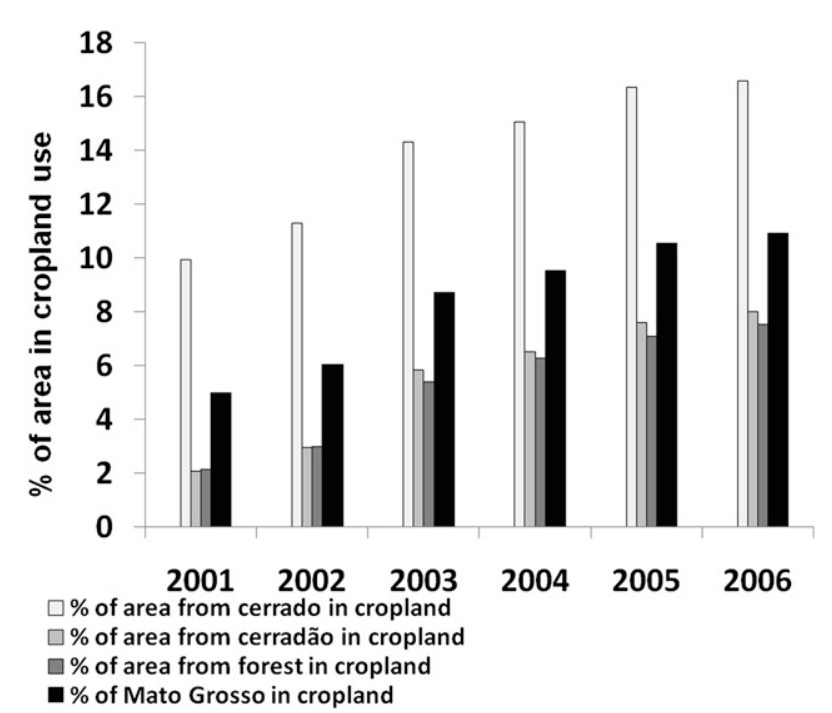

Figure 4. The percentage of land in cropland use in each originating biome and for the entire state.

\subsubsection{Double-cropping intensification}

Double cropping increased significantly over the period 2001-06, occurring on less than 2\% (15 $991 \mathrm{~km}^{2}$ ) of Mato Grosso in 2001 and $4.25 \%\left(39359 \mathrm{~km}^{2}\right.$ ) of the state by 2006 . Averaged over the study period, double cropping accounts for $40 \%$ of all croplands but is not uniformly distributed across the natural ecosystems (Figure 7).

Rates of conversion to double cropping vary by source land cover and land use (Figure 8). By biome, cerrado has the largest overall level of double-cropping intensification, with double-cropping patterns at almost $50 \%$ of all croplands (Figure 8). Double-cropping patterns account for an annual average of $47 \%$ of cerrado croplands, increasing their share of the cerrado land cover from $4 \%$ to $8 \%$ over the study period. Cerradão and forest both have double-cropping patterns in less than half the cropland area. In the cerradão system, double-cropping rates as a percentage of all cropland area in cerradão ranged from a low of 18\% in 2003 to a high of $30 \%$ in 2004. Double cropping increased over threefold during the study period in the forested region, ending with 3\% double-cropping land use.

\subsection{Estimated greenhouse gas emissions}

We estimate an annual average of $179 \mathrm{Tg} \mathrm{CO}_{2}-\mathrm{e} \mathrm{yr}^{-1}$ emissions from cropland extensification in Mato Grosso (Figure 9), with forest-to-cropland transitions having the highest carbon emissions at $126 \mathrm{Tg} \mathrm{yr}^{-1} \mathrm{CO}_{2}$-e. In forest-to-cropland transitions, methane emissions average $12 \mathrm{Tg} \mathrm{CO}_{2}-\mathrm{e} \mathrm{yr}^{-1}$ from forest biomass burning. Cerrado-to-crop, cerradão-to-crop, and pasture-to-crop transitions have modest emissions $\left(17,16\right.$, and $21 \mathrm{Tg} \mathrm{CO}_{2}-{\mathrm{e} \mathrm{yr}^{-1}}^{-1}$, respectively). Emissions from 


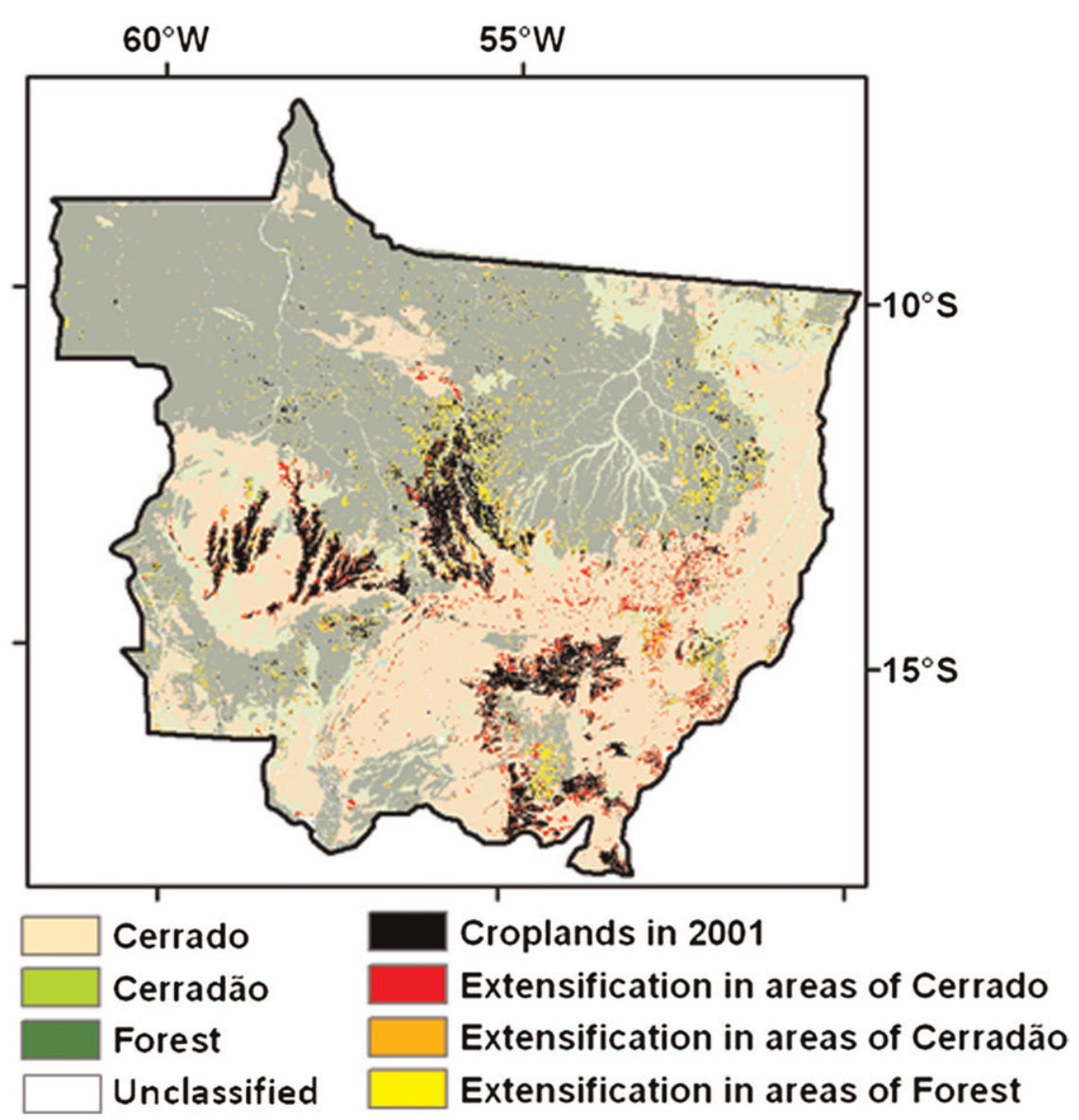

Figure 5. Agricultural cropland extensification (new areas of cropland from 2001 to 2006) mapped by natural ecosystem of origin, largely nucleating from existing croplands.

fertilizer additions are comparatively low at $0.4 \mathrm{Tg} \mathrm{CO}_{2}$-e $\mathrm{yr}^{-1}$, two-thirds of which we estimate from fertilizer applied in areas of double cropping.

By adding existing and nonredundant estimates, we developed a relatively complete greenhouse gas budget for Mato Grosso (Table 5). The combined estimates are $422.5 \mathrm{Tg} \mathrm{CO}_{2}$-e $\mathrm{yr}^{-1}$. It includes estimates of carbon losses from forest conversion to pasture and cropland, from natural ecosystem and pasture conversions to cropland, and from pasture maintenance fires and cattle emissions of methane (DeFries et al. 2008; after Steudler et al. 1996).

\section{Discussion}

\subsection{Land-use change}

A growing human population along with dietary changes is expanding the global area of agriculture, with the southern Amazon being one of the most rapidly 
Earth Interactions • Volume 14 (2010) • Paper No. 15 • Page 14
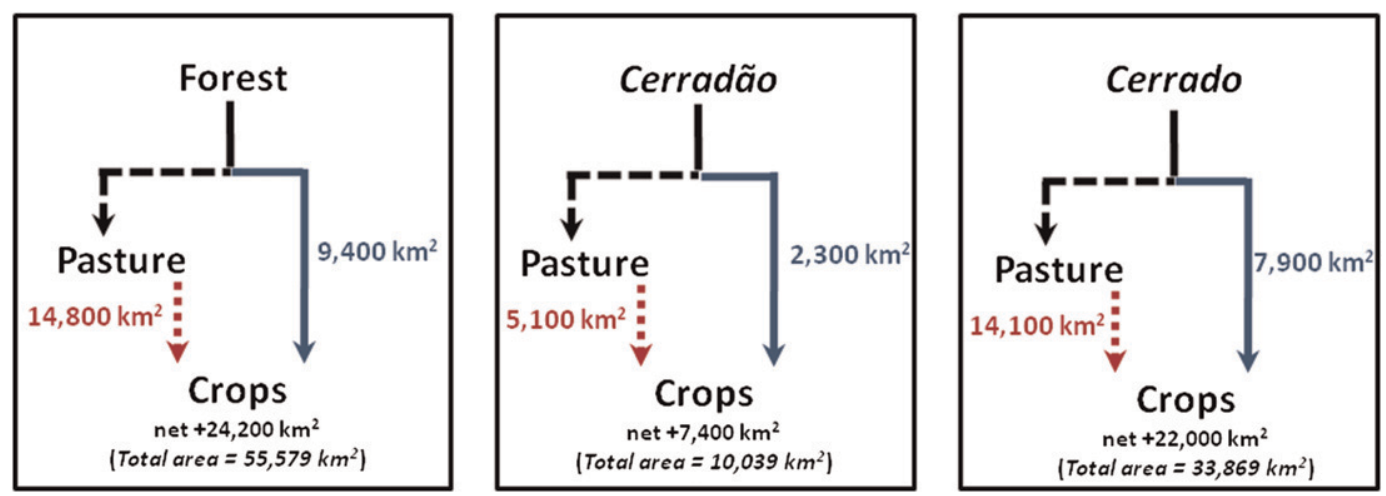

Figure 6. Transitions to croplands detected with remote sensing from 2001 to 2006. The two primary cropland development paths analyzed in this paper (transitions of natural ecosystem directly to cropland or pasture to cropland) are illustrated for each of the natural ecosystems of origin. The net cropland is total increase in cropland area from either land-use trajectory. The total area is the cropland area in 2006 that came from either trajectory. Also, see Table 4 for annual transition rates.

growing agricultural regions in the world. This and previous studies in the Amazon frontier have documented rapid land-use change for pastures and croplands and point out the differing land-use trajectories within the region (Brown et al. 2007; Galford et al. 2008; Morton et al. 2006). Here, we show that remote sensing techniques track landscape-level processes of cropland extensification and doublecropping intensification with temporal and spatial detail not provided by census or agricultural surveys. We document that the average annual rate of agricultural extensification $(0.47 \%$ increase each year) doubled from the 1990-96 annual rate $(0.24 \%)$ reported in the agricultural census data (IBGE 2009). We estimate slightly higher rates of forest conversion to cropland (average $>1500 \mathrm{~km}^{2} \mathrm{yr}^{-1}$ ) as compared to previous studies (average $1350 \mathrm{~km}^{2} \mathrm{yr}^{-1}$; Morton et al. 2006). This could

Table 4. The relative importance of pasture-to-cropland transitions as a percentage of all transition in each of the three major biomes in Mato Grosso. The year of conversion is the year prior to the first crop harvest. For example, an area converted in 2005 would first be harvested in 2006, so only conversions between 2001 and 2006 are reported here. See Figure 4 for net (area) transitions along each land-use trajectory.

\begin{tabular}{|c|c|c|c|}
\hline Year of conversion & \multicolumn{3}{|c|}{ Pasture-to-cropland transitions (percent of all cropland transitions) } \\
\hline Natural ecosystem of origin & Cerrado & Cerradão & Forest \\
\hline 2002 & 60 & 67 & 64 \\
\hline 2003 & 66 & 65 & 60 \\
\hline 2004 & 82 & 78 & 68 \\
\hline 2005 & 42 & 67 & 53 \\
\hline Annual avg & 63 & 69 & 61 \\
\hline Std dev & 17 & 6 & 6 \\
\hline
\end{tabular}


Earth Interactions - Volume 14 (2010) • Paper No. 15 • Page 15

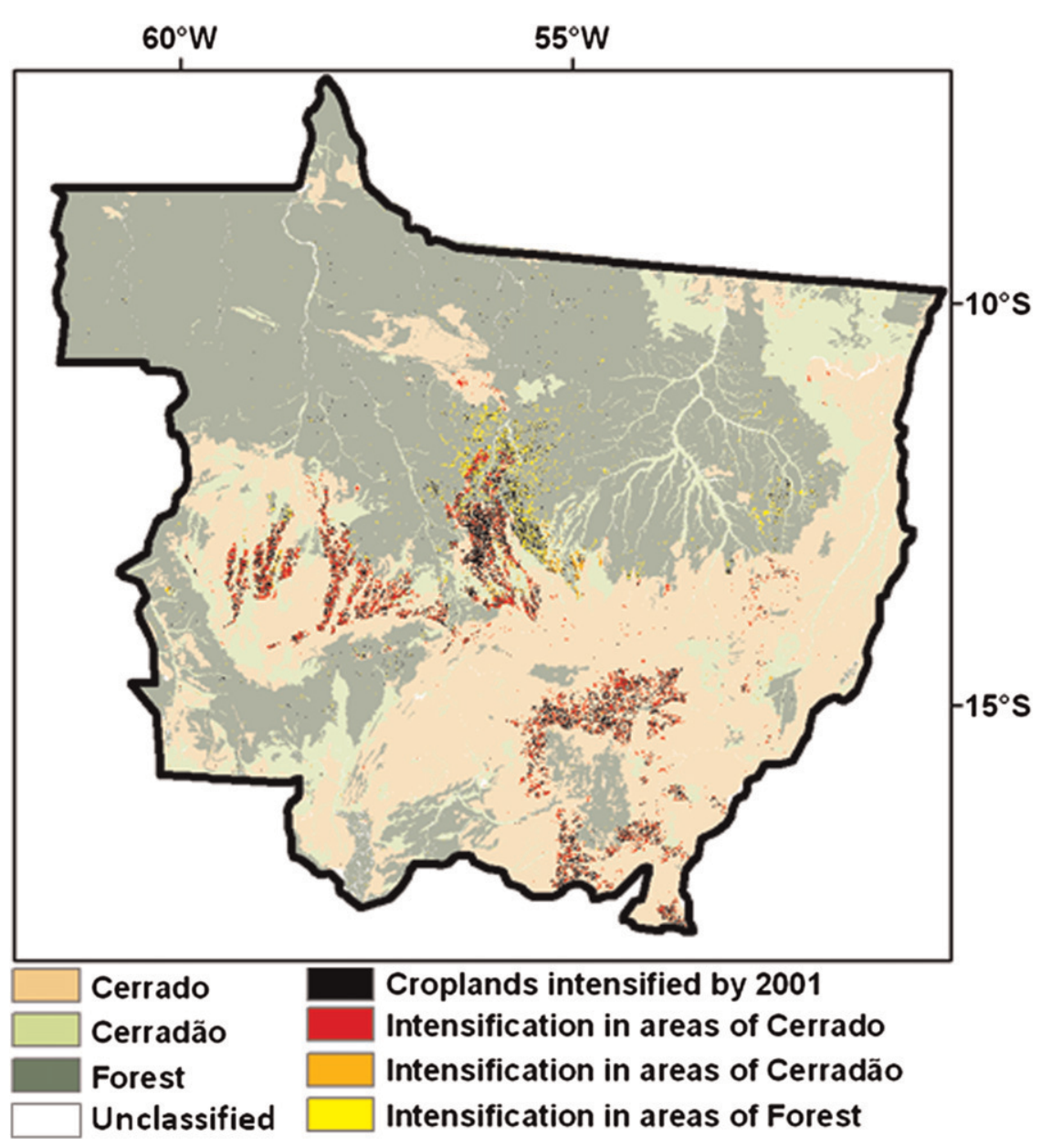

Figure 7. Agricultural cropland intensification is mapped by natural ecosystem of origin, where intensification is the transition from noncroplands or single-cropping patterns to double-cropping patterns between 2001 and 2006.

be for several reasons; our remote sensing algorithm is more specifically tuned for crop detection, we use different land-cover datasets to define the forest biomes, and the years included in the study are slightly different. Our analysis confirms that most lands moved into croplands do not revert to pasture or natural vegetation; in fact, as suggested by Rudel et al. (Rudel et al. 2005), croplands show little reversal to natural vegetation at least over the period studied in this region.

We observe high interannual variability in intensification and extensification rates within each biome. Extensification was particularly high between the years 2002 and 2003 and occurred mainly in cerrado areas. The cerrado is favorable for extensification for two reasons. First, it has some of the oldest croplands in the state, and existing croplands serve as nucleation centers for new cropland because infrastructure is already in place and farm equipment is easily moved between fields. Second, it is easier to clear cerrado than it is to clear cerradão or forest, 


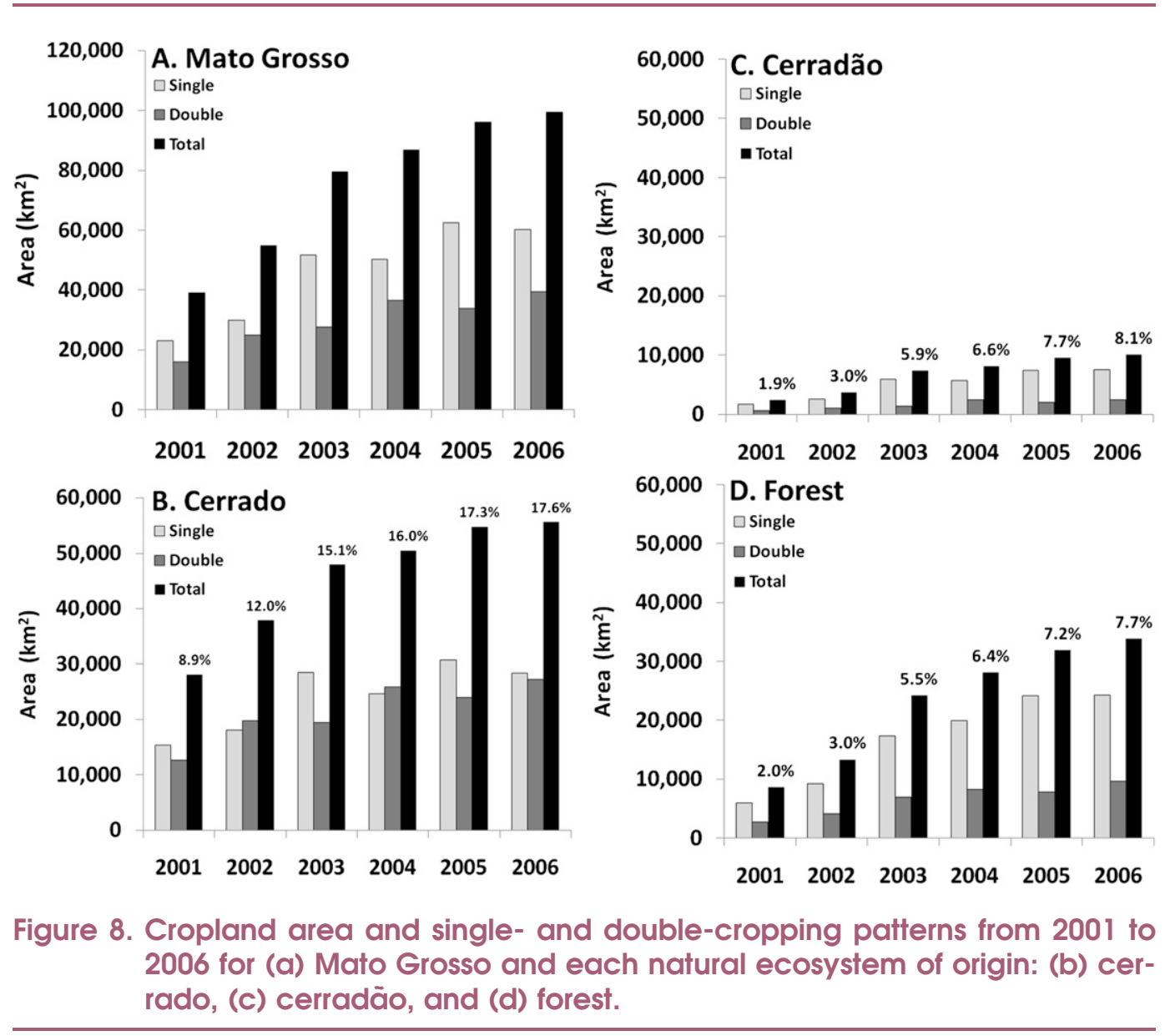

because cerrado has lower above-ground biomass and smaller root structures, which make it easier to clear for croplands.

Extensification rates for cerrado-to-cropland transitions slow in 2005 and 2006, whereas double-cropping intensification continues to increase. The increased double cropping in cerrado may be due to a shift in the relative profits from Brazilian soybeans dropping with the falling Brazilian currency in 2004 (Nepstad et al. 2006), which likely made intensification more cost effective than extensification at that time. Further, double cropping is more widespread in the cerrado than in other biomes, because double-cropping intensification generally occurs a few years after extensification and there is a longer history of extensification in the cerrado (primarily southern Mato Grosso). For croplands from areas of forest and cerradão, extensification continues steadily, whereas intensification rates remain low. Existing croplands from the forest and cerradão biomes represent a potential target for intensification that follows environmentally sound production guidelines.

The process of cropland development is dynamic and the land-cover and landuse change story does not stop at land clearing. Suitable areas for mechanized croplands need to be large and amenable to large-scale mechanized agriculture: for 


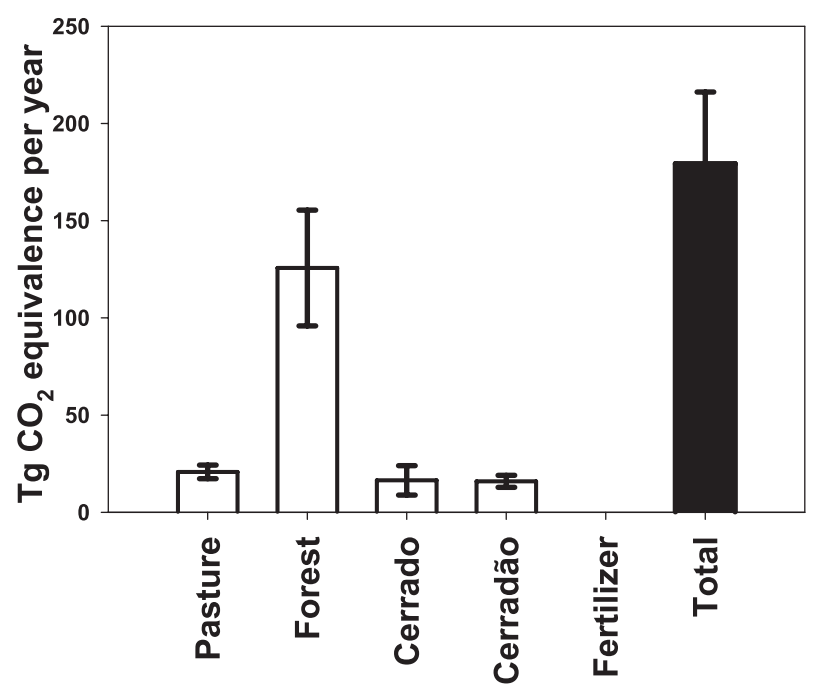

Figure 9. Greenhouse gas emissions from biomass loss and fertilizer additions. Pasture represents cropland extensification into areas of pasture that were previously created from areas of native vegetation. The range of emissions comes from a low, mid-, and high range of biomass estimates (Table 4).

example, fairly level topography (Jasinski et al. 2005). Lands are cleared through slash and burn until there are no roots or slash to foul machinery. To prepare for planting crops, soils may be amended with lime to reduce the aluminotoxicity; fertilized with nitrogen, phosphorus, and potassium; and often planted for 1-2 years with upland rice (Barbosa Filho and Yamada 2002; Fundação Agrisus 2006; Sanchez et al. 1982). The large-scale nature of croplands in the Amazon frontier is coupled both to scale dependence of profitable farming and the investors who will encourage that scale. From our observations, extensification of new single crops largely proceeds by expanding into adjacent lands rather than leaping to new

Table 5. Total annual greenhouse gas budget $\left(\mathrm{CO}_{2}\right.$-e emissions $\left.\mathrm{yr}^{-1}\right)$ for Mato Grosso accounting for conversions to pasture and cropland, pasture maintenance, and methane emissions from cattle. This budget accounts for cattle emissions using a mean emission rate of $55 \mathrm{~kg}$ methane per head (Steudler et al. 1996) and a cattle herd of 19600000 for Mato Grosso (IBGE 2009).

\begin{tabular}{llr}
\hline \multicolumn{1}{c}{ Emissions estimate } & $\mathrm{Tg} \mathrm{CO}$-e yr \\
\hline DeFries et al. 2008 & Conversion of forest to pasture $\left(\mathrm{CO}_{2}, \mathrm{CH}_{4}\right)$ & 199.7 \\
Galford et al. (this paper) & Conversion of pasture and natural ecosystems & 178.9 \\
& $\quad$ to cropland $\left(\mathrm{CO}_{2}, \mathrm{CH}_{4}\right)$ & \\
DeFries et al. 2008 & Pasture maintenance $\left(\right.$ fire; $\left.\mathrm{CO}_{2}\right)$ & 22.0 \\
After Steudler et al. 1996 & Cattle herd $\left(\mathrm{CH}_{4}\right)$ & 21.5 \\
Galford et al. (this paper) & Cropland fertilization $\left(\mathrm{N}_{2} \mathrm{O}\right)$ & 0.4 \\
Total & & 422.5 \\
\hline
\end{tabular}


Earth Interactions - Volume 14 (2010) - Paper No. 15 • Page 18

Table 6. Comparison of select major components of the carbon cycle in Brazil.

\begin{tabular}{|c|c|c|c|c|}
\hline Region & Greenhouse gas source & $\mathrm{Tg} \mathrm{C} \mathrm{yr}^{-1}$ & Year of estimate & Reference \\
\hline Brazil & Fossil fuels & 89 & 2005 & Boden et al. 2008 \\
\hline \multirow[t]{5}{*}{ Amazon } & Forest clearing & 116 & 2006 & $\begin{array}{l}\text { Ministry of Science and } \\
\text { Technology } 2006\end{array}$ \\
\hline & Cerrado clearing & 52 & 2006 & $\begin{array}{l}\text { Ministry of Science and } \\
\text { Technology } 2006\end{array}$ \\
\hline & $\begin{array}{l}\text { Ecosystem dynamics driven by } \\
\text { remotely sensed phenology }\end{array}$ & 70,130 & 2000,2002 & Potter et al. 2009 \\
\hline & $\begin{array}{l}\text { Amazon fire emissions, } \\
\text { including deforestation }\end{array}$ & $200-500$ & 2003 & Van der Werf et al. 2003 \\
\hline & Deforestation & 100 & 1989-98 & Houghton et al. 2000 \\
\hline Mato Grosso & Cropland extensification & 46 & $2000-06$ & - \\
\hline
\end{tabular}

development distant from the previous cropland activity centers. This spatial clumping is highly evident in the cerrado region, where most croplands have been concentrated. We see that double cropping is commonly carried out in the densest regions of mechanized croplands, not outlying regions that are newly established. Double-cropping patterns (soy-corn) typically emerge after several years of single cropping (soy). The time lag of extensification explains why the highest rates of double cropping are found in the cerrado, because this is the oldest cropland region in the state and holds the greatest amount of cropland by bioregion.

\subsection{Greenhouse gas consequences}

Land-use changes across the globe have contributed 35\% of anthropogenic $\mathrm{CO}_{2}$ emissions over the last 150 years (Foley et al. 2005). In the global context, Mato Grosso accounts for over $2 \%$ of the contemporary global greenhouse gas emissions from land-cover and land-use changes (Denman et al. 2007) while comprising less than $1 \%$ of the Earth's land surface. Annual greenhouse gas emissions from landuse extensification in Mato Grosso are equivalent to over half the Brazilian carbon emissions from fossil fuel burning and over $25 \%$ of all carbon emissions from Amazonian deforestation and from cerrado clearing (Table 6). Mato Grosso cropland extensification alone contributes at least half of the estimated $\mathrm{CO}_{2}$ losses from all biomass burning throughout Southern Hemisphere South America (Van der Werf et al. 2006). Our estimates show that methane emissions from biomass burning are small but account for roughly $10 \%$ of the greenhouse gas forcing of carbon emissions. Pasture is still the dominant land use in the Amazon and Mato Grosso, but this work shows new clearing for cropland extensification accounts for almost half of Mato Grosso's total greenhouse gas budget (Table 5). If current trends in land-use change continue, cropland extensification may become the largest regional source of greenhouse gas emissions.

Greenhouse gas emissions in Mato Grosso related from $\mathrm{N}$ fertilizer in croplands are quite small today, totaling just $0.4 \mathrm{Tg} \mathrm{CO}_{2}-\mathrm{e} \mathrm{yr}^{-1}$. Depending on shifting crop types, fertilizer prices, and management strategies that affect soil fertility and/or nitrogen-use efficiency, there is potential for these emissions to grow substantially. Regional field trials show diminishing returns on increasing fertilizer application 
Earth Interactions V Volume 14 (2010) • Paper No. 15 • Page 19

(Mar et al. 2003; Souza and Sorrato 2006), suggesting increasing N fertilization in this region may lead to increased $\mathrm{N}_{2} \mathrm{O}$ emissions without a proportional increase in crop productivity. We lack information on $\mathrm{N}_{2} \mathrm{O}$ production from soybean fields and how this changes over time (e.g., years planted in soy).

Remaining uncertainties in the total greenhouse gas budget could be clarified through total cost accounting that includes emissions from termite mounds; other animal sources; and postclearing soil biogeochemistry dynamics of based on management, such as the impacts of tillage practices on soil carbon storage (Cerri et al. 2004).

\subsection{Ecosystems consequences}

This work provides information on the mosaic of landscape heterogeneity, landcover types, and length of crop cover as it changes with single and double cropping that may be useful in future climate modeling efforts. These large-scale changes in land cover in the Amazon have distant teleconnections in the global climate system (e.g., increased precipitation in the U.S. Midwest; Avissar and Werth 2005). Climate research in the Amazon shows that, locally, cleared lands adjacent to natural ecosystems can alter convection patterns, leading to increased dry season cloud cover, increased high energy storms, and stronger storm clouds (Ramos da Silva et al. 2008; Baidya Roy and Avissar 2002). Croplands may have negative feedbacks to their own microclimate, as models show low stature vegetation becomes drier and warmer than the original natural ecosystems (Costa et al. 2007).

Land-use changes also affect the bidirectional relationship between biodiversity and ecosystem function. Here, we document the rate of disappearance of natural ecosystems and provide information on changes in cropland area that may be used to estimate impacts on biodiversity, while adding richness in understanding tradeoffs between agricultural development and natural ecosystem conservation. Species gains and losses related to changing habitats may alter ecosystem function. There are several ecosystems characteristics related to biodiversity that could be assessed with remote sensing methods. It is imperative to note that conservation of these uniquely diverse ecosystems and their associated species biodiversity is important in its own right and that ecosystem function and climate regulation are only a few of many additional reasons for conservation.

The agricultural mosaic of land use and the dynamic nature of croplands affect environmental and agricultural sustainability. The landscape configuration can have cascading affects on surrounding intact ecosystems. Information on land-use configurations in the matrix of natural land covers can be applied in conservation work to reduce environmental impacts, such as in protecting waterways and wildlife corridors (Green et al. 2005). The agricultural dynamics we observe suggest that cropland extensification and intensification will likely continue in this region through the coming decades. Thus, conservation priorities must focus on 1) increasing double cropping over new extensification to reduce the regional carbon emissions and preserve other ecosystem services while responding to global product demand and 2) understanding and communicating best management practices for croplands that synergistically reduce the environmental impact of croplands and increase farm production. 
Earth Interactions - Volume 14 (2010) - Paper No. 15 • Page 20

\section{Conclusions}

As suggested by Morton et al. (Morton et al. 2006), new land clearing for croplands is an emerging force that is rapidly increasing in the Brazilian agricultural frontier. We have verified this trend using a new set of detection algorithms, while enhancing the story of cropland dynamics, by tracking single crops maturing to double-cropping patterns. Intensification through double cropping is emerging as a new and major component of regional land uses, with rapid increases along with extensification. Information from remote sensing on the location and extent of cropping patterns is a useful addition to other datasets, such as deforestation detections and crop surveys conducted by the Brazilian government. There are a wide range of applications and implications from these cropland dynamics. Here, we estimate the greenhouse gas implications of cropland extensification and intensification; however, to assess the environmental impacts more comprehensively, we need to consider the consequences of these cropland changes for local and regional climate, hydrology, and biodiversity.

Acknowledgments. This work was supported by the NASA Earth and Space Science Fellowship (G. L. Galford) and Large-Scale Biosphere Atmosphere Experiment in Amazonia (Grant NNG06GE20A) and the Environmental Change Initiative at Brown University. We kindly thank colleagues Cindy Moreira, Marcos Neto, and CENA for their assistance in field research. A special thanks to J. Christopher Brown, Claudia Stickler, and their colleagues for the use of their field data. We are grateful to Kim Cahill, Leah VanWey, and David Kicklighter for their comments on an earlier version of this manuscript.

\section{References}

Adams, J. B., D. E. Sabol, V. Kapos, R. A. Filho, D. A. Roberts, M. O. Smith, and A. R. Gillespie, 1995: Classification of multispectral images based on fractions of endmembers: Application to land-cover change in the Brazilian Amazon. Remote Sens. Environ., 52, 137-154.

Alves, D. S., 2002: Space-time dynamics of deforestation in Brazilian Amazonia. Int. J. Remote Sens., 23, 2903-2908.

Anderson, L. O., Y. E. Shimabukuro, R. S. Defries, and D. Morton, 2005: Assessment of deforestation in near real time over the Brazilian Amazon using multitemporal fraction images derived from Terra MODIS. IEEE Trans. Geosci. Remote Sens., 2, 315-318.

Andreae, M. O., and P. Warneck, 1994: Global methane emissions from biomass burning and comparison with other sources. Pure Appl. Chem., 66, 162-169.

Avissar, R., and D. Werth, 2005: Global hydroclimatological teleconnections resulting from tropical deforestation. J. Hydrometeor., 6, 134-145.

Baidya Roy, S., and R. Avissar, 2002: Impact of land use/land cover change on regional hydrometeorology in Amazonia. J. Geophys. Res., 107, 8037, doi:10.1029/2000JD000266.

Barbosa Filho, M. P., and T. Yamada, 2002: Upland rice production in Brazil. Better Crops Int., 16, (Suppl.), 43-47.

Barona, E., 2008: Identifying the role of crop production in land cover change in Brazil, 1990-2006. M.S. thesis, Department of Geography, McGill University, Montreal, 140 pp.

Boden, T. A., G. Marland, and R. J. Andres, 2008: Global, regional, and national $\mathrm{CO}_{2}$ emissions. Carbon Dioxide Information Analysis Center Rep., doi:10.3334/CDIAC/00001_V2010.

Boserup, E., 1965: The Conditions of Agricultural Growth: The Economics of Agrarian Change under Population Pressure. George Allen and Unwin Limited, 108 pp.

Broch, D. L., and R. S. Pedroso, 2008: Custo de Produção da Cultura do Milho. Fundação MS, 1 pp. 
Earth Interactions • Volume 14 (2010) • Paper No. 15 • Page 21

— and —_ 2009: Milho Safrinha e Culturas de Inverno 2009. Fundação MS, 1 pp.

Brown, J. C., M. Koeppe, B. Coles, and K. P. Price, 2005: Soybean production and conversion of tropical forest in the Brazilian Amazon: The case of Vilhena, Rondônia. Ambio, 34, 462-469.

— - W. E. Jepson, J. H. Kastens, B. D. Wardlow, J. M. Lomas, and K. P. Price, 2007: Multitemporal, moderate-spatial-resolution remote sensing of modern agricultural production and land modification in the Brazilian Amazon. GIScience Remote Sens., 44, 117-148.

Buschbacher, R., C. Uhl, and E. A. S. Serrão, 1988: Abandoned pastures in eastern Amazonia. II. Nutrient stocks in the soil and vegetation. J. Ecol., 76, 682-699.

Castro, E. A., and J. B. Kauffman, 1998: Ecosystem structure in the Brazilian Cerrado: A vegetation gradient of aboveground biomass, root mass and consumption by fire. J. Trop. Ecol., 14, $263-$ 283.

Cerri, C. C., M. Bernoux, C. E. P. Cerri, and C. Feller, 2004: Carbon cycling and sequestration opportunities in South America: The case of Brazil. Soil Use Manage., 20, 248-254.

Cerri, C. E. P., and Coauthors, 2007: Simulating SOC changes in 11 land use change chronosequences from the Brazilian Amazon with the RothC and Century models. Agric. Ecosyst. Environ., 122, 46-57.

Cofer, W. R., III, J. Levine, E. Winstead, D. Cahoon, D. Sebacher, J. Pinto, and B. Stocks, 1996: Source compositions of trace gases released during African savanna fires. J. Geophys. Res., 101 (D19), 23 597-23 602.

Conservation International, cited 2008: Cerrado. Biodiversity hotspots. [Available online at http:// www.biodiversityhotspots.org/xp/hotspots/cerrado/Pages/default.aspx.]

Costa, M. H., S. N. M. Yanagi, P. J. O. P. Souza, A. Ribeiro, and E. J. P. Rocha, 2007: Climate change in Amazonia caused by soybean cropland expansion, as compared to caused by pastureland expansion. Geophys. Res. Lett., 34, L07706, doi:10.1029/2007GL029271.

Crutzen, P. J., A. R. Mosier, K. A. Smith, and W. Winiwarter, 2008: $\mathrm{N}_{2} \mathrm{O}$ release from agro-biofuel production negates global warming reduction by replacing fossil fuels. Atmos. Chem. Phys., 8, 389-395.

Cruz, J. C., and Coauthors, 2005: Resposta de Cultivares de Milho à Adubação Nitrogenada em Cobertura. P. e. A. Ministério de Agricultura, 4 pp.

Dale, V. H., S. M. Pearson, H. L. Offerman, and R. V. O'Neill, 1994: Relating patterns of land-use change to faunal biodiversity in the central Amazon. Conserv. Biol., 8, $1027-$ 1036.

de Carvalho, H. W. L., and Coauthors, 2008: Cultivares de milho, feijão, girassol, e mandioca para o Agrest Sergipano com foco na Agricultura Familiar e no Agronegócio. Embrapa Tabulerios Costeiros Document 131, $31 \mathrm{pp}$.

DeFries, R., and Coauthors, 2008: Fire-related carbon emissions from land use transitions in southern Amazonia. Geophys. Res. Lett., 35, L22705, doi:10.1029/2008GL035689.

Denman, K. L., and Coauthors, 2007: Couplings between changes in the climate system and biogeochemistry. Climate Change 2007: The Physical Science Basis, S. Solomon et al., Eds., Cambridge University Press, 499-587.

Edgar, J., 2007: IFB CropWatchers. FarmWeek, 16 Nov, Illinois Farm Bureau, Bloomington, Illinois.

Fearnside, P. M., 2001: Soybean cultivation as a threat to the environment in Brazil. Environ. Conserv., 28, 23-28.

Foley, J. A., and Coauthors, 2005: Global consequences of land use. Science, 309, 570-574.

Forster, P., and Coauthors, 2007: Changes in atmospheric constituents and in radiative forcing. Climate Change 2007: The Physical Science Basis, S. Solomon et al., Eds., Cambridge University Press, 129-234.

Fundação Agrisus, 2006: Rally da Safra 2006: Situação do plantio direto e da integração lavourapecuária no Brasil. Agroconsult, 25 pp. 
Earth Interactions - Volume 14 (2010) • Paper No. 15 • Page 22

Galford, G. L., 2010: Biogeochemical consequences of land-cover and land-use changes in the agricultural frontier of the Brazilian Amazon. Ph.D., Brown University, 249 pp.

— J. F. Mustard, J. Melillo, A. Gendrin, C. C. Cerri, and C. E. P. Cerri, 2008: Wavelet analysis of MODIS time series to detect expansion and intensification of row-crop agriculture in Brazil. Remote Sens. Environ., 112, 576-587.

Green, R. E., S. J. Cornell, J. P. W. Scharlemann, and A. Balmford, 2005: Farming and the fate of wild nature. Science, 307, 550-555.

Gregory, P. J., and Coauthors, 2002: Environmental consequences of alternative practices for intensifying crop production. Agric. Ecosyst. Environ., 88, 279-290.

Hansen, M. C., and Coauthors, 2008: Humid tropical forest clearing from 2000 to 2005 quantified by using multitemporal and multiresolution remotely sensed data. Proc. Natl. Acad. Sci. USA, 105, 9439-9444.

Hao, W. M., and D. E. Ward, 1993: Methane production from global biomass burning. J. Geophys. Res., 98, (D11), 20 657-20 661.

Houghton, R. A., D. L. Skole, C. A. Nobre, J. L. Hackler, K. T. Lawrence, and W. H. Chomentowski, 2000: Annual fluxes of carbon from deforestation and regrowth in the Brazilian Amazon. Nature, 403, 301-304.

— - K. T. Lawrence, J. L. Hackler, and S. Brown, 2001: The spatial distribution of forest biomass in the Brazilian Amazon: A comparison of estimates. Global Change Biol., 7, 731-746.

Huete, A., K. Didan, T. Miura, E. P. Rodriguez, X. Gao, and L. G. Ferreira, 2002: Overview of the radiometric and biophysical performance of the MODIS vegetation indices. Remote Sens. Environ., 83, 195-213.

IBGE, 2002: Pesquisas Agropecuárias. Ministério do Planejamento, Orçamento e Gestão, 96 pp.

— - cited 2009: Banco de Dados Agregados: Sistem IBGE de Recuperação Automática (SIDRA). [Available online at http://www.sidra.ibge.gov.br/.]

INPE, cited 2008: Sistema DETER. Instituto Nacional de Pesquisas Espaciais. [Available online at http://www.inpe.br.]

ITT, 2008: ENVI reference guide, version 4.6. ITT Visual Information Solutions.

Jasinski, E., D. Morton, R. DeFries, Y. Shimabukuro, L. Anderson, and M. Hansen, 2005: Physical landscape correlates of the expansion of mechanized agriculture in Mato Grosso, Brazil. Earth Interactions, 9. [Available online at http://EarthInteractions.org.]

Jenson, J. R., 2005: Thematic map accuracy assessment. Introductory Digital Image Processing: A Remote Sensing Perspective, Pearson Prentice Hall, 495-513.

Jepson, W., J. C. Brown, and M. Koepe, 2008: Agricultural intensification on Brazil's Amazonian soybean frontier. Land Change Science in the Tropics: Changing Agricultural Landscapes, A. Millington and W. Jepson, Eds., Springer, 73-92.

Justice, C. O., 1998: The Moderate Resolution Imaging Spectroradiometer (MODIS): Land remote sensing for global change research. IEEE Trans. Geosci. Remote Sens., 36, 1228-1249.

Keys, E., and W. H. McConnell, 2005: Global change and the intensification of agriculture in the tropics. Global Environ. Change, 15, 320-337.

Klink, C. A., and R. B. Machado, 2005: Conservation of the Brazilian cerrado. Conserv. Biol., 19, 707-713.

Longo, K. M., S. R. Freitas, M. O. Andreae, R. Yokelson, and P. Artaxo, 2009: Biomass burning in Amazonia: Emissions, long-range transport of smoke and its regional and remote impacts. Amazonia and Global Change, Geophys. Monogr., Vol. 186, Amer. Geophys. Union 207-232.

Mar, G. D., M. E. Marchetti, L. C. Ferreira de Souza, M. C. Gonçalves, and J. O. Novelino, 2003: Fertilidade do solo e nutricao de plantas: Producao do milho safrinha em funcao de doses e epocas de aplicacao de nitrogenio. Bragantia, 62, 267-274.

Mello, F., 2007: Estimativas dos estoques de carbono dos solos nos Estados de Rondônia e Mato Grosso anteriores à intervenção antrópica. Universidade de São Paulo, 89 pp. 


\section{Earth Interactions - Volume 14 (2010) • Paper No. 15 • Page 23}

Ministry of Science and Technology, 2006: Carbon dioxide emissions and removals from forest conversion and abandonment of managed lands. First Brazilian Inventory of Anthropogenic Greenhouse Gas Emissions, Brazilian Ministry of Science and Technology, 93 pp.

Morton, D. C., R. S. DeFries, Y. E. Shimabukuro, L. O. Anderson, F. del Bon Espírito-Santo, M. Hansen, and M. Carroll, 2005: Rapid assessment of annual deforestation in the Brazilian Amazon using MODIS data. Earth Interactions, 9. [Available online at http://EarthInteractions. org.]

,,,---- E. Arai, F. del Bon Espírito-Santo, R. Freitas, and J. Morisette, 2006: Cropland expansion changes deforestation dynamics in the southern Brazilian Amazon. Proc. Natl. Acad. Sci. USA, 103, 14 637-14 641.

— — — J. T. Randerson, L. Giglio, W. Schroeder, and G. R. Van der Werf, 2008: Agricultural intensification increases deforestation fire activity in Amazonia. Global Change Biol., 14, 2262-2275.

— — - and Y. E. Shimabukuro, 2009: Cropland expansion in cerrado and transition forest ecosystems: Quantifying habitat loss from satellite-based vegetation phenology. Cerrado Land Use and Conservation, Advanced Applied Biodiversity Science, C. A. Klink, Ed., Conservation International, in press.

Myers, N., R. A. Mittermeier, C. G. Mittermeier, G. A. B. da Fonseca, and J. Kent, 2000: Biodiversity hotspots for conservation priorities. Nature, 403, 853-858.

Nepstad, D. C., C. M. Stickler, and O. T. Almeida, 2006: Globalization of the Amazon soy and beef industries: Opportunities for conservation. Conserv. Biol., 20, 1595-1603.

Nogueira, E. M., P. M. Fearnside, B. W. Nelson, R. I. Barbosa, and E. W. H. Keizer, 2008: Estimates of forest biomass in the Brazilian Amazon: New allometric equations and adjustments to biomass from wood-volume inventories. For. Ecol. Manage., 256, $1853-1867$.

Potter, C., S. Klooster, A. Huete, V. Genovese, M. Bustamante, L. Guimaraes Ferreira, R. C. de Oliveira, Jr., and R. Zepp, 2009: Terrestrial carbon sinks in the Brazilian Amazon and Cerrado region predicted from MODIS satellite data and ecosystem modeling. Biogeosciences, 6, 937-945.

Ramos da Silva, R., D. Werth, and R. Avissar, 2008: Regional impacts of future land-cover changes on the Amazon basin wet-season climate. J. Climate, 21, 1153-1170.

Rezende Pereira, J. L. A., R. G. Von Pinho, I. D. Borges, A. M. A. Rezende Pereira, and T. G. Lima, 2009: Cultivares, doses de fertilizantes e densidades de semeadura no cultivo de milho safrinha. Cienc. Agrotecnol., 33, 676-683.

Rudel, T. K., O. T. Coomes, E. Moran, F. Achard, A. Angelsen, J. Xu, and E. F. Lambin, 2005: Forest transitions: Towards an understanding of global land use change. Global Environ. Change, 14, 23-31.

Saatchi, S. S., R. A. Houghton, R. C. Dos Santos Alvalá, and J. V. Soares, 2007: Distribution of aboveground live biomass in the Amazon basin. Global Change Biol., 13, 816-837.

,-- D. D. Alves, and B. Nelson, 2009: LBA-ECO LC-15 Amazon basin aboveground live biomass distribution map: 1990-2000. Oak Ridge National Laboratory Distributed Active Archive Center, 9 pp.

Sanchez, P. A., D. E. Bandy, J. H. Villachica, and J. J. Nicholaides, 1982: Amazon basin soils: Management for continuous crop production. Science, 216, 821-827.

Scanlon, T. M., and G. Kiely, 2003: Ecosystem-scale measurements of nitrous oxide fluxes for intensely grazed, fertilized grassland. Geophys. Res. Lett., 30, 1852-1856.

Shukla, J., C. Nobre, and P. Sellers, 1990: Amazon deforestation and climate change. Science, 247, $1322-1325$.

Skole, D., and C. Tucker, 1993: Tropical deforestation and habitat fragmentation in the Amazon: Satellite data from 1978 to 1988. Science, 260, 1905-1910.

Souza, E. F. C., and R. P. Sorrato, 2006: Efeito de fonts e doses de nitrogênio em cobertura, no milho safrinha, em plantio direto. Rev. Bras. Milho Sorgo, 5, 395-405. 
Earth Interactions - Volume 14 (2010) • Paper No. 15 • Page 24

Steudler, P. A., J. M. Melillo, B. J. Feigl, C. Neill, M. C. Piccolo, and C. C. Cerri, 1996: Consequence of forest-to-pasture conversion on CH4 fluxes in the Brazilian Amazon basin. J. Geophys. Res., 101, (D13), 18 547-18 554.

Turner, B. L., II, and A. M. A. Ali, 1996: Induced intensification: Agricultural change in Bangladesh with implications for Mathus and Boserup. Proc. Natl. Acad. Sci. USA, 93, 14 98414991.

Van der Werf, G., T. Randerson, G. J. Collatz, and L. Giglio, 2003: Carbon emissions from fires in tropical and subtropical ecosystems. Global Change Biol., 9, 547-562.

_ J. T. Randerson, L. Giglio, G. J. Collatz, P. S. Kasibhatla, and A. F. Arellano Jr., 2006: Interannual variability in global biomass burning emissions from 1997 to 2004. Atmos. Chem. Phys., 6, 3423-3441.

Earth Interactions is published jointly by the American Meteorological Society, the American Geophysical Union, and the Association of American Geographers. Permission to use figures, tables, and brief excerpts from this journal in scientific and educational works is hereby granted provided that the source is acknowledged. Any use of material in this journal that is determined to be "fair use" under Section 107 or that satisfies the conditions specified in Section 108 of the U.S. Copyright Law (17 USC, as revised by P.IL. 94553) does not require the publishers' permission. For permission for any other from of copying, contact one of the copublishing societies. 